\title{
Motivasi Belajar Siswa Dalam Pembelajaran Bahasa Arab di Madrasah ‘Aliyah Hamalatul-Qur'an Sanden
}

\author{
1*Mega Primaningtyas, ${ }^{2}$ Lusiana \\ 12STAI Masjid Syuhada Yogyakarta \\ E-mail: 1*megaprimaningtyas@hotmail.com
}

Tanggal Submitt: 16/11/2021 Tanggal diterima: 18/11/2021 Tanggal Terbit: 25/12/2021

\begin{abstract}
Abstrak: Penelitian ini dilandasi oleh tujuan yang ingin diketahui tentang bagaimana motivasi belajar siswa serta upaya yang dilakukan siswa dalam meningkatkan motivasi belajar dalam pembelajaran bahasa Arab di Madrasah 'Aliyah Hamalatul-Qur'an Sanden. Metode penelitian yang digunakan adalah dengan metode kualitatif deskriptif yaitu metode yang menggambarkan tentang keadaan di lapangan melalui observasi, wawancara, quesioner dan dokumentasi untuk pengambilan sumber data. Subjek penelitian adalah siswa kelas XI Aliyah. Analisis data dilakukan dengan cara reduksi data, penyajian data dan penarikan kesimpulan. Instrumen yang digunakan dalam penelitian ini menggunakan wawancara, quesioner (angket) dan dokumentasi. Hasil dari penelitian ini bahwa : 1) Mayoritas siswa memiliki motivasi belajar yang baik hal itu ditunjukkan dengan sikap belajar yang fokus, antusias dan tidak mengantuk. Namun masih ada beberapa siswa yang memiliki motivasi yang rendah hal itu ditunjukkan dengan terlihat cepat bosan dan tidak antusias mengikuti pelajaran. 2) Siswa yang mempunyai motivasi belajar yang baik mereka telah melakukan upaya untuk meningkatkan motivasi belajarnya dengan cara belajar kelompok, membuat jadwal belajar yang teratur dan bertanya kepada guru tentang pembelajaran bahasa Arab.
\end{abstract}

Kata kunci: Motivasi, Belajar, Pembelajaran, Bahasa Arab

$$
\begin{aligned}
& \text { تمدف هذه الدراسة إلى تحديد الدافع وراء تعلم الطلاب في تعليم اللغة العربية في المدرسة الثانوية "حمالة } \\
& \text { القرآن" ساندين. هذا النوع من البحث الكيفي مع المدخل الوصفي. }
\end{aligned}
$$

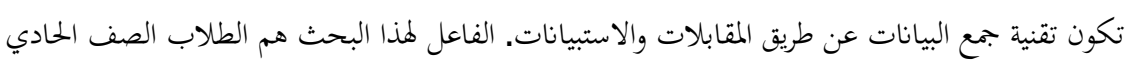

$$
\begin{aligned}
& \text { عشر. إن طريقة جمع البيانات هي المقابلة، الإستبيان، والتوثيق. إن طريقة تحليل بياناتا هي بطريق تقليل } \\
& \text { البيانات وعرض البيانات واستخلاص النتائج. } \\
& \text { وكانت نتيجة بحثه هي أن دافع تعلم الطلاب في تعليم اللغة العربية : 1) فبعض الطابات واب يركزون لا ينامون, } \\
& \text { والبعض الآخر يبدون بالملل متحمسين.2) بذل الطلاب جهودا لزيادة دافع التعلم لديهم من خلال الدراسة في } \\
& \text { مجموعات ووضع جدوال الدراسة وسؤال المعلم. }
\end{aligned}
$$

\section{PEMBAHASAN}

Motivasi mendorong timbulnya tingkah laku, mempengaruhi dan merubahnya, yamg mana dengan adanya motivasi maka tingkat keberhasilan siswa dalam pembelajaran bahasa Arab akan lebih baik dan hasilnya memuaskan baik bagi siswa itu 
sendiri bagi guru dan orang tua siswa. Motivasi belajar siswa merupakan faktor utama dalam keberhasilan belajar siswa. Siswa yang termotivasi dengan baik akan menghasilkan tingkat keberhasilan yang lebih baik. ${ }^{1}$

Motivasi siswa dalam pembelajaran bahasa Arab di Madrasah Hamalatul Qur'an Sanden memiliki tantangan tersendiri karena suasana belajar di asrama berbeda dengan kondisi belajar di rumah. Siswa yang bersekolah di sana datang dari berbagai daerah di Indonesia yang memiliki latar belakang yang berbeda-beda. Motivasi belajar mereka pun berbeda-beda, sebagaian mereka dengan kesadaran sendiri dapat memacu semangat dan motivasi dalam mengikuti pembelajaran, sedangkan sebagian yang lain motivasi belajarnya masih rendah.

Hal tersebut menjadi masalah jika motivasi siswa masih rendah dalam pembelajaran, karena akan berpengaruh pada rendahnya nilai pada mata pelajaran tersebut, tidak adanya kompetensi antar siswa yang akhirnya akan menurunnya prestasi yang dicapai siswa. Berdasarkan latar belakang dan fokus masalah penelitian di atas, maka permasalahan dapat dirumuskan sebagai berikut : 1) Bagaimana motivasi belajar siswa pada pembelajaran bahasa Arab ?, 2) Bagaimana upaya siswa dalam memotivasi dirinya agar lebih baik dalam pembelajaran bahasa Arab ?

\section{PEMBAHASAN}

\section{A. Motivasi Belajar Siswa}

\section{Pengertian Motivasi}

Dalam Kamus Umum Bahasa Indonesia disebutkan bahwa motivasi adalah dorongan yang timbul pada diri seseorang secara sadar atau tidak sadar untuk melakukan suatu tindakan dengan tujuan tertentu, atau usahausaha yang dapat menyebabkan seseorang atau kelompok orang tertentu tergerak melakukan sesuatu karena ingin mencapai tujuan yang dikehendakinya atau mendapat kepuasan dengan perbuatannya. ${ }^{2}$

Motivasi berasal dari kata "motif" yang dapat diartikan sebagai "daya penggerak yang telah menjadi aktif". Motif menjadi aktif pada saat-saat tertentu,terutama bila kebutuhan utuk mencapai sangat dirasakan/mendesak.

Menurut Santrock dalam Mardianto, motivasi adalah proses yang memberi semangat, arah dan kegigihan perilaku yang penuh energi, terarah dan bertahan lama. Sedangkan menurut Mulyasa motivasi adalah tenaga pendorong atau penarik yang menyebabkan tingkah laku ke arah suatu tujuan

1 Siti Nurhasanah, Pentingnya Motivasi Dalam Mendorong Minat Belajar Siswa (Jurnal : Indonesia Approach Education tahun 2020), Mahasiswi S1 PGSD Universitas Muhammadiyah Makasar

${ }^{2}$ Kompri, Motivasi Pembelajaran Perspektif Guru dan Siswa, (Bandung:Rosdakarya 2016), hal 1 
tertentu. Peserta didik akan bersungguh-sungguh karena memiliki motivasi yang tinggi. Seorang siswa akan belajar bila ada faktor pendorongnya yaitu motivasi. $^{3}$

Dikemukakan oleh Dimyati dan Mudjiyono, bahwa ada beberapa unsur yang mempengaruhi motivasi belajar siswa yaitu : cita-cita dan aspirasi siswa, kemampuan siswa, kondisi siswa dan kondisi lingkungan siswa. ${ }^{4}$ Jadi dapat disimpulkan bahwa motivasi belajar adalah keseluruhan daya penggerak di dalam diri siswa yang menimbulkan kegiatan belajar yang menjamin kelangsungan dan memberikan arah pada kegiatan belajar untuk mencapai tujuan.

\section{Fungsi Motivasi}

Fungsi motivasi menurut Oemar Hamalik, adalah mendorong timbulnya perilaku seperti perbuatan belajar, motivasi juga berfungsi untuk mengarahkan perbuatan pada sesuatu yang diinginkan dan motivasi sebagai penggerak yang menentukan cepat atau lambatnya suatu pekerjaan. ${ }^{5}$

Indikator motivasi menurut Newstrom adalah untuk menunjukkan tingkat antusiasme, inisiatif dan usaha terus menerus, meningkatkan komitmen dengan keterikatannya dengan organisasi dan menunjukkan tindakan organizational citizenship, memenuhi kepuasan dan harapan. ${ }^{6}$

\section{Jenis-jenis Motivasi}

Menurut Dimyati dan Mudjiono, motivasi sebagai kekuatan mental individu memiliki dua jenis tingkat kekuatan :

a. Motivasi Primer, yaitu motivasi yang didasarkan pada motif-motif dasar, yang berasal dari segi biologis atau jasmani manusia.

b. Motivasi Sekunder, yaitu motivasi yang dipelajari, motif ini diakitkan dengan sosial,sikap dan emosi dalam belajar yang terkait dengan komponen penting seperti kognitif, efektif dan kuratif. ${ }^{7}$

Sumadi Suryabrata membedakan motif menjadi dua, yakni motif ekstrinsik dan motif intrinsik :

a. Motif ekstrinsik, yaitu motif-motif yang berfungsi karena adanya perangsangan dari luar, seseorang akan bangkit karena motivasi dari temannya, misalnya orang belajar giat karena diberi tahu bahwa

\footnotetext{
3 Mulyasa, Kurikulum BerbasisKompetensi (Bandung: Remaja Rosdakarya, 2003),hal 112

${ }^{4}$ Dimyati, Belajar dan Pembelajaran (Jakarta:Depdikbud,2005) hal 80

${ }^{5}$ Kompri, Motivasi Pembelajaran Perspektif Guru dan Siswa (Bandung : Rosdakarya:2016), hal:5

6 Ibid, hal 5

${ }^{7}$ Muhammad Nur Ihsan, Skripsi Motivasi Belajar Siswa Dalam Pembelajaran PAI, 2016
} 
sebentar lagi ada ujian, maka orang akan melakukan sesuatu seperti membaca karena ada pemberitahuan, bersemangat ketika mengerjakan tugas secara berkelompok.

b. Motif intrinsik, yaitu motif-motif yang berfungsi tidak perlu dirangsang dari luar. Timbul karena keinginan diri sendiri, karena hobi atau kesadaran diri sendiri. Seperti orang yang rajin bangun lebih awal, dan bertanggung jawab tidak usah menunggu perintah dari orang lain. ${ }^{8}$ Contoh lain yaitu membaca, mencari buku pelajaran penunjang dan lain sebagainya, bertanya kepada guru atau teman yang lebih paham.

Motivasi ekstrinsik dan intrinsik sangat penting bagi siswa dalam proses belajar. Timbulnya motivasi intrinsik pada siswa terkadang diawali dengan adanya motivsi ekstrinsik, oleh karenanya peran motivator eksternal dalam hal ini guru dan orang tua serta teman sangat besar sehingga dapat mempengaruhi timbulnya motivasi intrinsik bagi siswa.

Menurut Davis D and Newstrom ada empat pola motivasi yang sangat penting dalam menjalani kehidupan seseorang yaitu :

a. Prestasi, yaitu dorongan untuk mengatasi tantangan, untuk maju dan berkembang

b. Afiliasi, yaitu dorongan untuk berhubungan dengan orang-orang secara efektif

c. Kompetensi, yaitu dorongan untuk mencapai hasil kerja dengan kualitas tinggi

d. Kekuasaan, yaitu dorongan untuk memengaruhi orang-orang dan situasi. ${ }^{9}$

\section{Teori Motivasi}

Terdapat beberapa teori motivasi menurut para ahli yang dikemukakan oleh Purwanto dalam bukunya Psikologi Pendidikan, yaitu :

a. Teori Hedonisme, yaitu motivasi yang cenderung mementingkan kehidupan yang penuh kesenangan dan kenikmatan duniawi.

b. Teori Naluri, yaitu kebiasaan dan tingkah laku yang diperbuat sehari-hari manusia berdasarkan naluri mana yang akan dituju dan dikembangkan.

c. Teori Reaksi yang Dipelajari, teori ini berpandangan bahwa tindakan atau perilaku manusia tidak berdasarkan naluri-naluri, tetapi berdasarkan pola-pola tingkah laku yang dipelajari dari kebudayaan di tempat manusia itu berada. Menurut teori ini apabila seorang pendidik akan

${ }^{8}$ Kompri, Motivasi Pembelajaran (Bandung:Remaja Rosdakarya, 2016), hal 6

${ }^{9}$ Kompri, Motivasi Pembelajaran Prespektif Guru dan Siswa (Bandung : Remaja Rosdakarya,2016), hal 7 
memotivasi siswanya, pendidik itu hendaknya mengetahui benar-benar latar belakang kehidupan dan kebudayaan siswanya.

d. Teori Kebutuhan, teori ini beranggapan bahwa tindakan yang dilakukan oleh manusia pada hakikatnya adalah untuk memenuhi kebutuhannya, baik kebutuhan fisik maupun psikis. Oleh karena itu, menurut teori ini, apabila seorang pendidik bermaksud memberi motivasi kepada siswanya, maka pendidik harus mengetahui kebutuhan-kebutuhan dari siswa yang akan dimotivasinya. Salah satu tokoh yang terkenal dengan teori kebutuhan dasarnya (heararchy of needs) yaitu Abraham Maslow, mengemukakan adanya lima tingkatan kebutuhan pokok manusia, yaitu : 1) kebutuhan fisiologis, 2) kebutuhan rasa aman, 3) kebutuhan sosial, 4) kebutuhan penghargaan, 5) kebutuhan aktualisasi diri.10 Menurut Maslow, kebutuhan dasar harus dipenuhi dahulu sebelum memuaskan atau memenuhi kebutuhan yang lebih tinggi, misalnya : siswa harus memuaskan dulu kebutuhan makan sebelum mereka dapat berprestasi. ${ }^{11}$

\section{Prinsip-prinsip Motivasi Belajar}

Prinsip-prinsip motivasi yang dapat diterapkan dalam proses pembelajaran disebut model ARCS, yaitu :

a. Attention (Perhatian)

Rasa ingin tahu dari peserta didik akan melahirkan perhatian, maka perhatian yang sudah tertanam akan menjadi stimulus bagi peserta didik untuk menjaga motivasinya selama proses pembelajaran. Contohnya siswa tertarik dalam pembelajaran karena gaya mengajar guru yang humoris.

b. Relevance (Pertalian/hubungan)

Relevansi menunjukkan adanya hubungan materi pembelajaran dengan kebutuhan dan kondisi peserta didik. Seperti materi pembelajaran bahasa Arab tentang muhadasah (percakapan) yang di dalamnya terdapat dialog dengan bahasa yang mudah dipahami.

\section{c. Confidence (Percaya Diri)}

Potensi untuk dapat berinteraksi adalah dengan merasa diri kompeten. Prinsip yang berlaku dalam hal ini adalah bahwa motivasi akan meningkat sejalan meningkatnya harapan untuk berhasil. Seperti percaya diri bisa tampil dan mempresentasikan pelajaran di depan siswa yang lain.

d. Satisfaction (Kepuasan)

\footnotetext{
${ }^{10}$ Ibid, hal 8

${ }^{11}$ Muhammad Nur Ihsan, Skripsi Motivasi Belajar Siswa Dalam Pembelajaran PAI, 2016
} 
Kepuasan dihasilkan dari keberhasilan dalam mencapai suatu tujuan, hal ini dipengaruhi oleh faktor luar atau dalam diri individu tersebut. Untuk meningkatkan dan memelihara motivasi peserta didik, dapat menggunakan pemberian berupa pujian, nilai yang bagus, kesempatan dan sebagainya. Contoh siswa yang rajin mengerjakan tugas dengan tepat waktu diberi nilai plus, siswa yang aktif di kelas mendapat nilai baik untuk keaktifannya. ${ }^{12}$

\section{Faktor-faktor Yang mempengaruhi Motivasi Belajar}

Menurut Dimyati dan Mudjiono, faktor-faktor yang mempengaruhi motivasi belajar adalah sebagai berikut :

a. Cita-cita atau aspirasi siswa, keberhasilan mencapai keinginan dapat menumbuhkan kemauan belajar yang akan menimbulkan cita-cita dalam kehidupan. Contoh cita-cita ingin melanjutkan pendidikan ke sekolah yang lebih tinggi, siswa akan bersungguh-sungguh dalam belajar, mengikuti pembelajaran dengan antusias, mengerjakan tugas tepat waktu dan sebagainya.

b. Kemauan siswa, cita-cita siswa harus dibarengi dengan kemauan, yaitu kemauan untuk belajar sungguh-sungguh, mengerjakan tugas tepat waktu dan berusaha meningkatkan pengetahuannya.

c. Kondisi siswa, kondisi siswa yang sehat jasmani dan rohaninya akan mempengaruhi motivasi belajar, siswa yang sehat akan lebih bersemangat dan antusias dalam mengikuti pembelajaran, sebaliknya jika siswa dalam keadaan sakit maka sikap belajar siswa akan terganggu seperti mengantuk di kelas, duduk bersandar malas atau tidak fokus ketika guru menjelaskan pelajaran di kelas.

d. Kondisi lingkungan siswa, faktor lingkungan sekitar siswa sangat mempengaruhi siswa dalam motivasi belajarnya. Kondisi lingkungan yang sehat, tenang, nyaman dan rukun akan membangkitkan semangat belajar siswa. Begitu pula sebaliknya, jika lingkungan sekitar siswa kotor, tidak nyaman (panas atau sumpek) dan berisik akan mempengaruhi kualitas siswa dalam pembelajaran. ${ }^{13}$

Faktor-faktor tersebut sangat berpengaruh pada motivasi belajar siswa, hal tersebut akan menimbulkan keinginan dan semangat untuk mengembangkan aktivitas, inisiatif dan memelihara ketekunan dalam pembelajaran.

12 Blogspot.Ipmpriau.kemendikbud.go.id

${ }^{13}$ Dimyati dan Mudjiono, Belajar dan Pembelajaran (Jakarta:Rineka Cipta, 2002) 


\section{Upaya Dalam Meningkatkan Motivasi Belajar}

Proses pembelajaran akan berhasil manakala siswa mempunyai motivasi dalam belajar. Berikut ini beberapa petunjuk untuk meningkatkan motivasi belajar siswa :

a. Mempunyai tujuan yang ingin dicapai, tujuan yang jelas akan membuat siswa paham ke arah mana ia ingin dibawa. Pemahaman siswa terhadap tujuan pembelajaran dapat menumbuhkan minat siswa untuk belajar dengan itu dapat meningkatkan motivasi belajar mereka.

b. Membangkitkan minat, siswa akan terdorong untuk belajar manakala mereka memiliki minat untuk belajar. Hal ini merupakan salah satu teknik dalam mengembangkan motivasi belajar. Menurut Anni dan kawan-kawan, tujuan yang penting dalam pembelajaran adalah membangkitkan hasrat ingin tahu siswa mengenai pelajaran yang akan datang, dan karena itu pembelajaran akan mampu meningkatkan motivasi intrinsik siswa untuk mempelajari materi pelajaran yang diajarakan guru.

c. Menciptakan suasana yang menyenangkan dalam belajar, siswa akan dapat belajar dengan baik jika berada dalam suasana yang menyenangkan, merasa aman, dan nyaman baik di dalam kelas maupun di luar kelas.

d. Variasi penyajian pembelajaran yang menarik dari guru, teknik ini dapat dilakukan oleh guru agar siswa tidak merasa bosan dengan metode dan media pembelajaran yang monoton. Pembelajaran yang menarik akan membangkitkan rasa ingin tahu siswa di dalam kegiatan pembelajaran selanjutnya, hal ini akan meningkatkan motivasi siswa dalam pembelajaran.

e. Mendapatkan pujian yang wajar dalam setiap keberhasilan siswa. Motivsi akan tumbuh manakala siswa merasa dihargai. Dalam pembelajaran pujian dapat menjadi alat meningkatkan motivasi. Siswa akan merasa senang karena dipuji. Pujian yang baik adalah pujian yang keluar dari hati seorang guru secara wajar dengan maksud untuk memberikan penghargaan atas jerih payah siswa dalam belajar.

f. Penilaian, nilai bagi sebagian siswa dapat menjadi motivasi yang kuat untuk belajar. Penilaian akan mendorong siswa giat belajar, setiap siswa cenderung untuk berusaha mendapatkan nilai yang baik.

g. Mendapatkan komentar dari hasil kerja, komentar yang positif merupakan penghargaan bagi siswa, walaupun hanya sebatas kata singkat seperti 
"bagus" atau "teruskan pekerjaanmu" dan sebagainya, komentar yang positif dapat meningkatkan motivsi belajar siswa.

h. Kompetisi yang sehat, kompetisi atau persaingan yang sehat akan menumbuhkan pengaruh yang baik untuk keberhasilan proses pembelajaran siswa. ${ }^{14}$

Dalam meningkatkan motivasi belajar ini banyak faktor pendukung baik dari diri siswa itu sendiri maupun dari luar yang dapat mempengaruhi kebiasaan siswa secara langsung maupun tidak langsung dalam mengikuti pembelajaran.

\section{Peran Guru Sebagai Motivator Siswa}

Guru dalam perannya sebagai motivator siswa adalah melakukan usahausaha dan menciptakan kondisi yang mengarahkan anak didik melakukan kegiatan dalam rangka meningkatkan pengembangan pembelajaran siswa.

Menurut Asmuni Syukur, ada tiga macam tugas guru yang paling pokok, yaitu:

a. Tugas Profesional, yaitu meliputi mendidik, mengajar dan melatih/membimbing serta meneliti (riset).

b. Tugas Sosial, yaitu misi yang diemban guru adalah misi kemanusian, yaitu guru di sekolah harus dapat menjadikan dirinya sebagai "orang tua kedua" bagi siswanya dan di masyarakat sebagai figur panutan "digugu dan ditiru".

c. Tugas Personal, dalam hal ini guru hendaknya memperhatikan diri sendiri sebagai pembelajaran agar mampu menarik simpatik siswanya, seperti memperhatikan penampilan fisik begitu juga hal kepribadian lainnya. ${ }^{15}$

Berkaitan dengan upaya guru dalam meningkatkan motivasi belajar siswa, French dan Raven dalam Djamarah menyarankan sejumlah cara, diantaranya :

a. Penggunaan pujian verbal

b. Pergunakan tes dan nuali secara bijaksana

c. Membangkitkan rasa ingin tahu dan hasrat eksplorasi

d. Memanfaatkan apersepsi siswa

e. Pergunakan simulasi dan permainan

f. Melakukan hal yang luar biasa

g. Meminta siswa untuk menggunakan hal-hal yang telah dipelajari sebelumnya.

\footnotetext{
${ }^{14}$ Djamarah dan Aswan Zain, Strategi Belajar-Mengajar (Jakarta : Rineka Cipta tahun 2006)

${ }^{15}$ Kompri, Motivasi Pembelajaran Prespektif Guru dan Siswa (Bandung : Remaja Rosdakarya, 2016), hal 39
} 
h. Memberi hadiah

i. Mengadakan kompetisi

j. Memberi hukuman

k. Tujuan yang diakui 16

Dalam pelaksanaannya, adakalaya guru mempergunakan teknikteknik tersebut secara kurang tepat, akibatnya justru merugikan prestasi belajar siswa, karena menurut Uno motivasi belajar siswa juga dapat dipengaruhi oleh faktor intrinsik dan ekstrinsik, seperti yang telah dikemukankan di atas.

\section{Motivasi Dalam Pembelajaran Bahasa Arab}

\section{a. Pengertian Motivasi dalam Pembelajaran Bahasa Arab}

Menurut Sardiman, motivasi dalam pembelajaran adalah "Keseluruhan daya penggerak di dalam diri siswa yang menimbulkan kegiatan belajar, yang menjamin kelangsungan dari kegiatan belajar dan memberikan arah pada kegiatan belajar, sehingga tujuan yang dikehendaki oleh subjek belajar itu dapat tercapai."

Adapun pembelajaran menurut Undang-Undang Sistem Pedidikan Nasional No.20 tahun 2003 adalah "proses interaksi peserta didik dengan pendidik dan sumber belajar pada suatu lingkungan belajar". Pembelajaran adalah "suatu kombinasi yang tersusun meliputi unsur-unsur manusiawi, material fasilitas, perlengkapan dan prosedur yang saling mempengaruhi tercapainya tujuan pembelajaran". ${ }^{17}$

Pembelajaran adalah proses interaksi peserta didik dengan pendidik dan sumber belajar pada suatu lingkungan belajar. Pembelajaran merupakan bantuan yang diberikan pendidik agar dapat terjadi proses pemerolehan ilmu dan pengetahuan, penguasaan kemahiran dan tabiat, serta pembentukan sikap dan kepercayaan pada peserta didik. Dengan kata lain pembelajaran adalah proses untuk membantu peserta didik agar dapat belajar dengan baik. ${ }^{18}$

Motivasi dalam Pembelajaran bahasa Arab adalah "Keseluruhan daya penggerak di dalam diri siswa dalam proses interaksi antara peserta didik dan guru pada proses belajar bahasa Arab dengan tujuan memudahkan peserta didik dalam memahami bahasa Arab beserta ruang lingkupnya. ${ }^{19}$

${ }^{16}$ Ibid, hal 246

17 Oemar Hamalik, Kurikulum dan Pembelajaran (Jakarta :Bumi Aksara, 1995) hal 57

${ }^{18}$ Abin Syamsudin Makmun, Psikologi Pendidikan (Bandung:Remaja Rosdakarya,2005) hal 156

${ }^{19}$ Abdul wahhab Rosyidi, Media Pembelajaran Bahasa Arab, (Malang:UIN-Malang Press,20009) hal 17 
Dengan mempelajari bahasa Arab, siswa dapat mempelajari AlQur'an, Hadiś, kitab-kitab berbahasa Arab dan sejarah serta literaturlitaratur berbahasa Arab dan sebagai alat komunikasi dalam pengembangan minat dan bakat di masyarakat.

\section{b. Tujuan Pembelajaran Bahasa Arab}

Menurut Dejnozka dan Kavel adalah suatu pernyataan spesifik yang dinyatakan dalam bentuk perilaku yang diwujudkan dalam bentuk tulisan yang menggambarkan hasil belajar yang diharapkan.

Adapun Menurut Slavin tujuan pembelajaran dirumuskan dalam bentuk perilaku kompetensi spesifik, aktual dan terukur sesuai yang diharapkan terjadi, dimiliki dan dikuasai siswa setelah mengikuti pembelajaran.

Tujuan pembelajaran bahasa Arab adalah siswa mampu memahami Al-Qur'an dan Hadits sebagai sumber hukum Islam dan ajarannya, mempu memahami dan mengerti buku-buku agama dan kebudayaan Islam yang tertulis dalam bahasa Arab, terampil berbicara dan mengarang dalam bahasa Arab, sejalan dengan tujuan umum pembelajaran yaitu untuk mencapai perubahan perilaku yang diharapkan oleh siswa dan pendidik setelah mengikuti kegiatan pembelajaran. Hasil pencapaiannya berwujud siswa yang secara bertahap terbentuk wataknya, kemampuan berpikir dan keterampilan teknologinya. ${ }^{20}$

\section{B. Upaya Siswa Dalam Meningkatkan Motivasi Belajar Bahasa Arab}

Seseorang yang rajin belajar berarti dia memiliki komitmen dalam belajar. Siswa yang rajin akan mengetahui caranya sendiri untuk membuat proses belajar menjadi lebih menyenangkan. Keadaan ini dipengaruhi oleh unsur-unsur yang dapat meningkatkan motivasi belajar siswa tersebut baik dari dirinya sendiri maupun dari luar. Kekuatan dorongan untuk meningkatkan motivasi belajar dari dalam diri siswa berupa keyakinan akan pentingnya suatu pembelajaran dan keingin tahuan yang besar. Adapun dorongan dari luar bisa berupa suasana kelas yang kondusif, guru yang memberi semangat, apresiasi dari orang tua dan guru. ${ }^{21}$

Upaya-upaya yang dapat dilakukan siswa untuk meningkatkan motivasi belajarnya dapat dilakukan dengan cara sebagai berikut :1) Niat yang kuat untuk maju, 2) Menyediakan jumlah waktu khusus untuk belajar, 3) Kerelaan untuk

\footnotetext{
${ }^{20}$ Junaenah Misbah, "Pendidikan Islam dalam Perspektif Teori dan Praktek" (Yogyakarta : Mentari Pustaka, 2013), hal.97

${ }^{21}$ Kompri, Motivasi Pembelajaran Persfektif Guru dan Siswa (Bandung: Remaja Rosdakarya:2016), hal 245
} 
meninggalkan kegiatan yang tidak terlalu penting, 4) Ketekunan dalam mengerjakan tugas, 5) Bekerjasama dengan teman yang mempunyai motivasi yang sama, 6) Selalu berdoa memohon kemudahan, 7) Memohon restu dari orang tua 22

Dorongan niat yang kuat, usaha yang maksimal dan berdo'a serta memohon restu dari orang tua, in syaa Allah akan melahirkan hasil yang memuaskan, semua itu ditunjang dengan lingkungan yang kondusif menjadi motivasi dan meningkatkan kualitas diri dalam pembelajaran.

\section{Sajian dan Analisis Data}

Pada bagian ini penulis akan memaparkan data dan hasil penelitian yang telah di rumuskan pada rumusan masalah yaitu tentang motivasi siswa dalam pembelajaran bahasa Arab dan upaya siswa dalam meningkatkan motivsi belajar kelas XI Madrasah Aliyah Hamalatul Qur'an Sanden Bantul.

\section{Motivasi Siswa Pada Pembelajaran Bahasa Arab}

Berdasarkan pengamatan penulis, motivasi belajar siswa kelas XI dalam pembelajaran bahasa Arab yaitu :

Pada sesi pertama pembelajaran, guru tiba di kelas mengucapkan salam dan siswa menjawab salam dalam keadaan tertib dan tenang. Kemudian guru mengawali pembukaan dengan berdo'a lalu bertanya kabar kepada siswa, dengan serempak siswa menjawab dan kembali memperhatikan guru. Siswa mempersiapkan buku pelajaran dan alat tulis. Pada sesi selanjutnya guru mengulang pelajaran yang sudah dipelajari dengan metode tanya jawab, siswa menjawab dengan semangat, selanjutnya guru memulai pada kegiatan inti yaitu membacakan materi baru dan menjelaskan dalam bahasa Arab dengan metode ceramah, setengah jam berlangsung guru menjelaskan materi pelajaran.

Suasana kelas mulai berubah pada menit selanjutnya, sebagian siswa secara kontinyu mengikuti pelajaran di kelas dengan tertib, walaupun terkadang diganggu dengan dengungan sayap lalat yang beterbangan di dalam kelas, siswa masih bisa fokus mengikuti pembelajaran, mereka duduk tegap dengan perhatian yang fokus pada guru di depan kelas. Namun sebagian siswa lainnya mulai terlihat duduk bersandar santai, ada yang bertopang dagu dan tampak mengantuk, sementara ada pula yang asik memainkan alat tulisnya untuk menghalau kebosanan.

Pada kesempatan terakhir, guru memberikan tugas kepada siswa dan bertanya tentang tugas yang diberikan pada pertemuan yang lalu, sebagian siswa telah menyelesaikan tugas dengan tepat waktu, namun ada pula siswa

22 Blogspot. Motivasi Belajar Siswa. Tahun 2018 
yang menunda-nunda bahkan belum mengerjakan tugas sampai batas waktu yang ditentukan.

Kegiatan siswa dalam motivasi belajar di luar jam pembelajaran tampak beragam, pada jam istirahat sebagian siswa memanfaatkan waktunya untuk merebahkan diri di dalam dan pelataran masjid, sebagian lainnya ada yang mengulang hafalan duduk menyendiri, sebagian lagi ada berdiskusi dengan teman-temannya.

Dari pemaparan di atas dapat disimpulkan bahwa sikap belajar siswa berbeda-beda dalam mengikuti pembelajaran, hal ini berpengaruh pada motivasi belajar siswa tersebut. Siswa yang mempunyai motivasi tinggi dapat dilihat dari sikap belajar yang antusias, aktif, fokus dan konsentrasi serta memahami tugas dan mengerjakannya tepat waktu. Hal tersebut menunjukkan bahwa siswa tersebut mempunyai cita-cita yang diinginkan dengan demikian siswa mempunyai kemauan untuk bangkit dan giat dalam pembelajaran, hal ini didukung oleh kondisi siswa pada saat itu dalam keadaan baik, sehat jasmani dan rohaninya serta lingkungan yang kondusif memacu siswa untuk lebih rajin dan semangat belajar. Dengan demikian siswa tersebut mempunyai motivasi intrinsik yang baik dan motivasi ekstrinsik yang mendukung dalam meningkatkan motivasi belajar.

Sedangkan siswa lain yang mengikuti pembelajaran dengan kurang antusias, tidak fokus, mengantuk, bosan dan tidak mengerjakan tugas tepat waktu, hal tersebut bisa diakibatkan karena kurangnya sikap kedewasaan, kurangnya minat dalam pembelajaran, lemahnya intelegensi dalam memahami pelajaran, tidak memahami tujuan dan cita-citanya atau tidak adanya bakat dalam dirinya dalam pelajaran tertentu, sehingga tidak ada kemauan dalam dirinya untuk berusaha lebih giat dan semangat dalam mengikuti pembelajaran. Keadaan ini juga bisa terjadi karena faktor dari luar yang mempengaruhi rendahnya motivasi belajar, seperti kurang dukungan dari orang tua, berteman dengan teman yang mempunyai motivasi rendah, ketidak nyamanan berada di lingkungan sekolah atau kurang tertariknya dengan metode guru saat menjelaskan pelajaran di kelas. Maka dapat disimpulkan bahwa siswa tersebut tidak memiliki motivasi intrinsik yang baik hal ini juga dipengaruhi oleh motivasi ekstrinsik yang reandah, sehingga siswa tidak dapat memahami kebutuhan dan tujuannya dalam pembelajaran.

\section{Upaya Siswa Dalam meningkatkan Motivasi Belajar}

Proses pembelajaran akan berhasil apabila siswa mempunyai motivasi dalam belajar. Pada penelitian ini, siswa yang mengikuti pembelajaran dengan semangat dan fokus adalah salah satu upaya mereka agar motivasi belajarnya 
terus berlangsung baik. Berbagai cara mereka lakukan untuk menjaga motivasi belajarnya, agar tujuan yang diinginkan tercapai, sebagian mereka membuat agenda belajar yang tertib, belajar kelompok, menyesuaikan cara belajar dengan kemampuan dirinya seperti dengan cara membaca, mendengar, menulis dan sebagainya yang menurut mereka dianggap lebih mudah memahami pelajaran.

Ketika siswa mempunyai minat pada pembelajaran mereka akan menunjukkan rasa ingin tahu yang besar dan berusaha memacu diri untuk dapat memhami pelajaran dengan baik, usaha-usaha tersebut bisa dilihat dari sebagian siswa yang senang dengan mengikuti pembelajaran sehingga mereka mendapatkan apresiasi/pujian dari guru maupun orang tuanya. Hal ini wajar karena siswa membutuhkan penghargaan atas setiap usahanya.

Adapun siswa yang tidak antusias, cepat bosan, mengantuk di kelas menunjukkan tidak adanya upaya mereka untuk meningkatkan motivasi belajar. Keadaan tersebut menandakan mereka tidak/kurang memahami tujuan dari pembelajaran, mereka tidak tahu akan dibawa kemana dirinya dengan keadaan seperti itu. Hal ini disebabkan karena tidak adanya minat dan bakat dalam pembelajaran, sehingga bagaimanapun metode penyajian guru dalam menjelaskan tidak berpengaruh terhadap motivasinya.

Keadaan yang demikian akan mengurangi upaya siswa untuk bisa berkompetisi, siswa tidak mempunyai daya saing yang baik sehingga hasil/nilai yang didapat tidak maksimal bahkan cenderung buruk, hal ini mengakibatkan jatuhnya prestasi yang dicapai.

\section{KESIMPULAN}

Berdasarkan hasil penelitian yang telah penulis lakukan, maka dapat disimpulkan bahwa motivasi belajar siswa kelas XI dalam pembelajaran bahasa Arab memiliki karakter yang berbeda-beda, sebagian siswa menunjukan motivasi belajar dengan antusias, bersungguh-sungguh, memperhatikan, fokus dan mengerjakan tugas dengan rajin. sebagian lagi terlihat kurang antusias, santai, diselingi dengan bercanda. Siswa yang kurang bersemangat dalam pembelajaran terlihat beberapa kali menguap dan mengantuk dan tampak tidak antusias.

Keadaan sikap belajar siswa yang berbeda-beda tersebut disebabkan karena faktor-faktor yang sangat mempengaruhi motivasi belajarnya seperti cita-cita siswa setelah selesai sekolah, kemauan siswa dalam meningkatkan minat belajarnya, kondisi kesehatan jasmani dan rohani siswa serta lingkungan dimana siswa itu berada.

Selain faktor-faktor tersebut dalam meningkatkan motivasi belajar harus didukung dengan upaya siswa yaitu mempunyai tujuan atau niat yang jelas, memupuk bakat dan minat, menciptkan suasana yang menyenangkan, menyarankan agar ada variasi 
pengajaran yang tidak membosankan dan berupaya agar mendapatkan apresasi/penghargaan dari guru dan orang tua yang menjadi penyemangat dalam mengikuti pembelajaran.

\section{DAFTAR PUSTAKA}

Siti Nurhasanah, Pentingnya Motivasi Dalam Mendorong Minat Belajar Siswa (Jurnal : Indonesia Approach Education tahun 2020), Mahasiswi S1 PGSD Universitas Muhammadiyah Makasar

Kompri, Motivasi Pembelajaran Perspektif Guru dan Siswa, (Bandung:Rosdakarya 2016)

Mulyasa, Kurikulum BerbasisKompetensi (Bandung: Remaja Rosdakarya, 2003)

Dimyati, Belajar dan Pembelajaran (Jakarta:Depdikbud,2005) hal 80

Kompri, Motivasi Pembelajaran Perspektif Guru dan Siswa (Bandung : Rosdakarya:2016),

Muhammad Nur Ihsan, Skripsi Motivasi Belajar Siswa Dalam Pembelajaran PAI, 2016

Dimyati dan Mudjiono, Belajar dan Pembelajaran (Jakarta:Rineka Cipta, 2002)

Djamarah dan Aswan Zain, Strategi Belajar-Mengajar (Jakarta : Rineka Cipta tahun 2006)

Oemar Hamalik, Kurikulum dan Pembelajaran (Jakarta :Bumi Aksara, 1995)

Abin Syamsudin Makmun, Psikologi Pendidikan (Bandung:Remaja Rosdakarya,2005)

Abdul wahhab Rosyidi, Media Pembelajaran Bahasa Arab, (Malang:UIN-Malang Press,20009)

Junaenah Misbah, "Pendidikan Islam dalam Perspektif Teori dan Praktek" (Yogyakarta : Mentari Pustaka, 2013) 